\title{
INVOLVEMENT OF BACTERIA IN THE ORIGIN OF A NEWLY DESCRIBED SPELEOTHEM IN THE GYPSUM CAVE OF GRAVE GRUBBO (CROTONE, ITALY)
}

\author{
Paola Cacchio ${ }^{*}$, Claudia Ercole ${ }^{1}$, Rosita Contento ${ }^{1}$, Giorgio Cappuccio², \\ Maria Preite Martinez ${ }^{3}$, Maddalena Del Gallo ${ }^{1}$, and Aldo Lepidi ${ }^{1}$
}

\begin{abstract}
Microorganisms have been shown to be important active and passive promoters of redox reactions that influence the precipitation of various minerals, including calcite. Many types of secondary minerals thought to be of purely inorganic origin are currently being reevaluated, and microbial involvement has been demonstrated in the formation of pool fingers, stalactites and stalagmites, cave pisoliths, and moonmilk. We studied the possible involvement of bacteria in the formation of a new type of speleothem from Grave Grubbo Cave, the third-largest gypsum cave in Italy. The speleothem we studied consisted of a large aggregate of calcite tubes having a complex morphology, reflecting its possible organic origin. We isolated an abundant heterotrophic microflora associated with this concretion and identified Bacillus, Burkholderia, and Pasteurella spp. among the isolates. All of the isolates precipitated $\mathrm{CaCO}_{3}$ in vitro in the form of calcite. Only one of the isolates solubilized carbonate. The relative abundance of each isolate was found to be directly related to its ability to precipitate $\mathrm{CaCO}_{3}$ at cave temperature. We suggest that hypogean environments select for microbes exhibiting calcifying activity. Isotopic analysis produced speleothem $\delta^{13} \mathrm{C}$ values of about $-5.00 \%$, confirming its organic origin. The lightest carbonates purified from B4M agar plates were produced by the most abundant isolates. SEM analysis of the speleothem showed traces of calcified filamentous bacteria interacting with the substrate. Spherical bioliths predominated among the ones produced in vitro. Within the crystals produced in vitro, we observed bacterial imprints, sometimes in a preferred orientation, suggesting the involvement of a quorum-sensing system in the calcium-carbonate precipitation process.
\end{abstract}

\section{INTRODUCTION}

Few gypsum karst systems in Italy have been studied in detail, but general features that distinguish these systems from limestone systems have nonetheless been identified. These karst systems normally contain small physical and chemical deposits with very similar morphologies and chemical compositions, but they may also contain unusual speleothems and cave minerals characteristic of gypsum caves.

Grave Grubbo Cave (Crotone, Southern Italy) contains two unusual calcite deposits (Forti and Lombardo,1998). The first is a floating calcite speleothem resembling a group of half-bubbles. The second is a newly discovered type of speleothem that was suspected to be of organic origin due to its complex structure composed of a large aggregate of iso-oriented calcite tubes. Poluzzi and Minguzzi (1998) have suggested that the origins of this speleothem may lie in the activities of a troglobitic insect that belongs to the order Trichoptera (genus Wormaldia?) and dwells in the sulfur compound-rich hypogean water. In theory, these insects would be throphically supported by nutrients synthesized by chemoautotrophic bacteria. In a hypogean environment, the presence of reduced chemical compounds, such as hydrogen sulfide, creates a redox interface between these compounds and the oxygen from the cave atmosphere or from oxygen-rich waters. Chemoautotrophic microorganisms can live at this interface by deriving energy from the oxidation of reduced chemical compounds. Specialized sulphur-oxidizing microbial communities, in particular, use this energy to produce organic matter in situ. Organic matter, in turn, can serve as the basis for a food chain that can sustain invertebrate communities inhabiting the deep recesses of hypogenic caves (Forti et al., 2002). On the other hand, the hypogean environment also hosts bacteria that use or produce large amounts of $\mathrm{CO}_{2}$ due to their metabolic activities. According to this theory, this $\mathrm{CO}_{2}$ reacts with the gypsum-saturated water in the presence of $\mathrm{Ca}^{2+}$, resulting in the deposition of calcite around the insect larvae. However, this deposition hypothesis does not account for the absence of insects in the speleothem body, the diameter of the calcite

\footnotetext{
*Corresponding Author: paolacacchio@yahoo.it

${ }^{1}$ Department of Basic and Applied Biology, Microbiology Laboratory, University of L'Aquila, Coppito, 67010 L'Aquila, Italy

${ }^{2}$ CNR- Institute of Structural Chemistry, POB 10, 00016 Monterotondo Sc., Rome, Italy

${ }^{3}$ Department of Earth Science - La Sapienza University and IGAG - CNR, Rome, Italy
} 
tubes being greater than that of the larvae, and the lack of evidence that continental Trichoptera can accumulate lithoid elements (Poluzzi and Minguzzi, 1998).

Many studies have demonstrated the effects of heterotrophic bacteria, actinomycetes in particular, on the formation of specific speleothems (Baskar et al., 2006, 2009; Cañaveras et al., 1999, 2001; Groth et al., 1999; Laiz et al., 1999, 2000; Le Métayer-Levrel et al., 1997; Melim et al., 2001; Northup et al., 2000). Bacteria can precipitate extracellular calcium carbonate through a variety of processes (Barton and Northup, 2007; Ehrlich, 2002; Riding, 2000; Simkiss and Wilbur, 1989). First, mineralization occurs as a byproduct of microbial metabolism that involves either autotrophic pathways, which can deplete $\mathrm{CO}_{2}$ locally, or heterotrophic pathways, which release into the environment (Castanier et al., 1999, 2000). In these passive mechanisms, reactions such as the enzymatic hydrolysis of urea, and the ammonification of amino acids cause a rise in $\mathrm{pH}$, which, if free $\mathrm{Ca}^{2+}$ is present, results in the precipitation of calcium carbonate.

Second, carbonate nucleation takes place on bacterial cell walls due to ion exchange (i.e., an active process) through the cell membrane by poorly understood mechanisms (Castanier et al., 1999). It may also occur through the adsorption of divalent cations to specific negatively charged functional groups on the cell wall (Rivadeneyra et al., 2000). Nevertheless, once carbonate has begun to precipitate on the cell surface, the cell acts as a nucleation site. This stage is critical in initiating mineral precipitation. Subsequent $\mathrm{CaCO}_{3}$ precipitation may be purely inorganic.

The third possibility involves specific proteins present in the extracellular polymeric substances (EPS) produced by the bacterial communities that can trap sediment and are often essential for a direct deposition of microbial carbonate (Ercole et al., 2007; Riding, 2000).

By growing microorganisms in the laboratory under controlled conditions, it is possible to delineate their ability to alter the chemistry of their microenvironment and produce biominerals. For this reason, we used laboratorybased cultures to investigate the extent to which heterotrophic calcifying bacteria are involved in the formation of the speleothem construction recently discovered in Grave Grubbo Cave. We isolated and characterized culturable heterotrophic microflora from the sample and assessed each isolate for in vitro calcification and carbonate solubilization at various temperatures. We also studied the mineral and isotopic compositions and the morphology of the carbonate concretion and of the purified bioliths obtained in laboratory cultures.

\section{Materials And Methods}

The Grave Grubbo Cave opens at $158 \mathrm{~m}$ above sea level in the gypsum karst of Verzino, on the Calabrian Ionian side, just at the foot of the Silan Massif (Crotone, Southern Italy; Fig. 1). Several deep karst landforms were recently discovered in this area, and the Grave Grubbo-Vallone Cufalo system is the main cave identified (Galdenzi and Menichetti, 1998). Grave Grubbo is the third-largest gypsum cave in Italy and extends to over $2 \mathrm{~km}$. Three galleries branch off from the cave entrance, the Ramo di Cenerentola, the Galleria quadrata, and the Ramo del fiume (Fig. 2; Forti and Lombardo, 1998). An underground river, the water of which contains sulfate and calcium ions, flows through the lower section of the main passage, the Ramo del fiume, and can be followed for about $1.5 \mathrm{~km}$. The temperature of the cave is about $15^{\circ} \mathrm{C}$. The rock formations, structural settlement of the karst formations in this area, and the hydrodynamics of this system are not consistent with the development of large, widespread chemical deposits. Indeed, calcite speleothems are very rare and small, and there are almost no gypsum speleothems.

We studied an unusual and likely biogenic speleothem in the Grave Grubbo Cave. The sample location and sample are shown in Figures 2 and 3, respectively.

The speleothems in Grave Grubbo Cave present as sectional massive or acicular structures, so it was clear, even to the first cavers who visited the cave, that this speleothem was remarkably different from other formations. Forti and Lombardo (1998) were the first to note the peculiar characters of the deposit and described it for a multidisciplinary research program on the Verzino area (Ferrini, 1998). The presence of this kind of speleothem inside Grave Grubbo is limited to a confined area next to a small waterfall and the terminal lake, at about three quarters of the total length of the cave.

The studied speleothem, made of calcite tubes connected together, mantled a limited evaporitic outcrop. From a lithological point of view, the deposit is divided into two separate levels, each having a different direction for its tubes' axes that likely resulted from two different flow directions during its period of deposition. At present, the speleothem has no connection with the actual water flow and appears to be fossilized.

A sample was collected from the upper layer of the speleothem using a sterile chisel and sample bag, and was stored at $4{ }^{\circ} \mathrm{C}$ for $24 \mathrm{~h}$ until microbiological analysis. From this sample, we obtained two sub-samples under sterile conditions. One contained material from the exterior surface of the speleothem (the "outer" subsample) and the other contained material from the speleothem's interior (the "inner" subsample).

To isolate the culturable heterotrophic bacteria associated with the outer and inner sub-samples from the upper layer of the speleothem, we ground $1 \mathrm{~g}$ of each sample to a powder using a sterile mortar and pestle and suspended this powder in saline solution $(0.9 \% \mathrm{NaCl})$. Serial dilutions were spread in triplicate on B-4 agar (Boquet et al., 1973) containg $2.5 \mathrm{~g}$ calcium acetate, $4.0 \mathrm{~g}$ yeast extract, $10.0 \mathrm{~g}$ glucose, and $18.0 \mathrm{~g}$ Biolife agar per liter of distilled water. The $\mathrm{pH}$ was adjusted to 8.0 using $\mathrm{NaOH}$. B-4 medium is an 


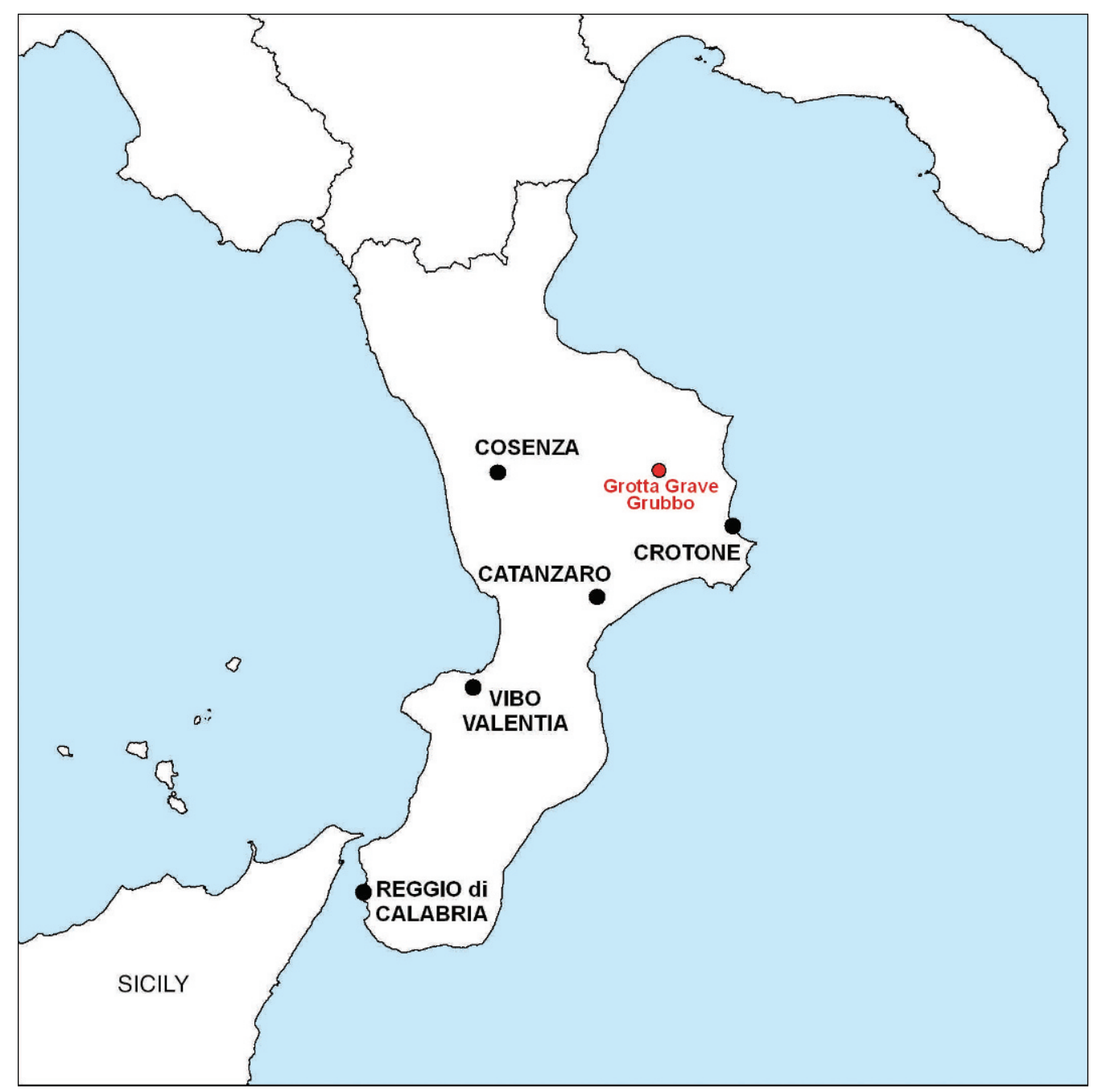

Figure 1. Geographical location of Grotta Grave Grubbo (Grave Grubbo Cave), Calabria, Southern Italy.

enrichment medium for calcifying bacteria; the acetate ion is an energy source, while the $\mathrm{Ca}^{2+}$ cation is used by the calcifying bacteria to precipitate calcium carbonate. The presence of glucose speeds the process. Inoculated plates were incubated at $32{ }^{\circ} \mathrm{C}$ for two weeks. Previous studies demonstrated that colonies from cave samples grow very slowly at cave temperature and that the diversity of the culturable genera was similar whether the bacteria were grown at cave temperature $\left(13{ }^{\circ} \mathrm{C}\right)$ or at laboratory temperature $\left(28{ }^{\circ} \mathrm{C}\right.$ ) (Groth et al., 2001; Laiz et al., 2003). Individual colonies were selected and purified by streaking on B-4 agar. The relative abundance of each isolate, with respect to the total culturable bacterial microflora, was determined by direct counts on B-4 agar plates. Pure calcifying isolates were stored in liquid nitrogen $\left(-196^{\circ} \mathrm{C}\right)$.

Calcifying isolates were characterized using morphophysiological and biochemical methods. Cell and aggregate morphology was studied under a light microscope. Gramstaining was performed with the Color Gram 2 kit (bioMérieux, Marcy-l'Etoile, France).
All physiological tests in which temperature was not a studied variable were carried out at $15{ }^{\circ} \mathrm{C}$. Oxygen requirement was studied by incubating isolates on B-4 agar in an anaerobic chamber. Oxidase activity was assessed using a solution of $\mathrm{N}, \mathrm{N}$-dimethyl p-phenylenediamine oxalate, ascorbic acid, and $\beta$-naphthol (Oxoid). Catalase production was demonstrated on slides by the formation of bubbles when a suspension of the organism to be tested was mixed with a drop of $3 \%(\mathrm{v} / \mathrm{v})$ hydrogen peroxide. Acid production was determined by API $50 \mathrm{CH}$, API STAPH, API 20E and API 20NE test strips (bioMérieux) according to the manufacturer's instructions. Urease activity, nitrate reduction, arginine dihydrolase, gelatinase, $\beta$-galactosidase, lysine decarboxylase, ornithine decarboxylase, and tryptophan deaminase activities and $\mathrm{H}_{2} \mathrm{~S}$ indole and acetoin production were also checked by API test strips (bioMérieux). APILAB Plus software (update v. 3.3.3) was used for the API test culture identification.

We assessed the calcite production of isolates by culturing them on medium B-4, as described by Boquet et al. (1973). The bacterial isolates were spread in triplicate on 


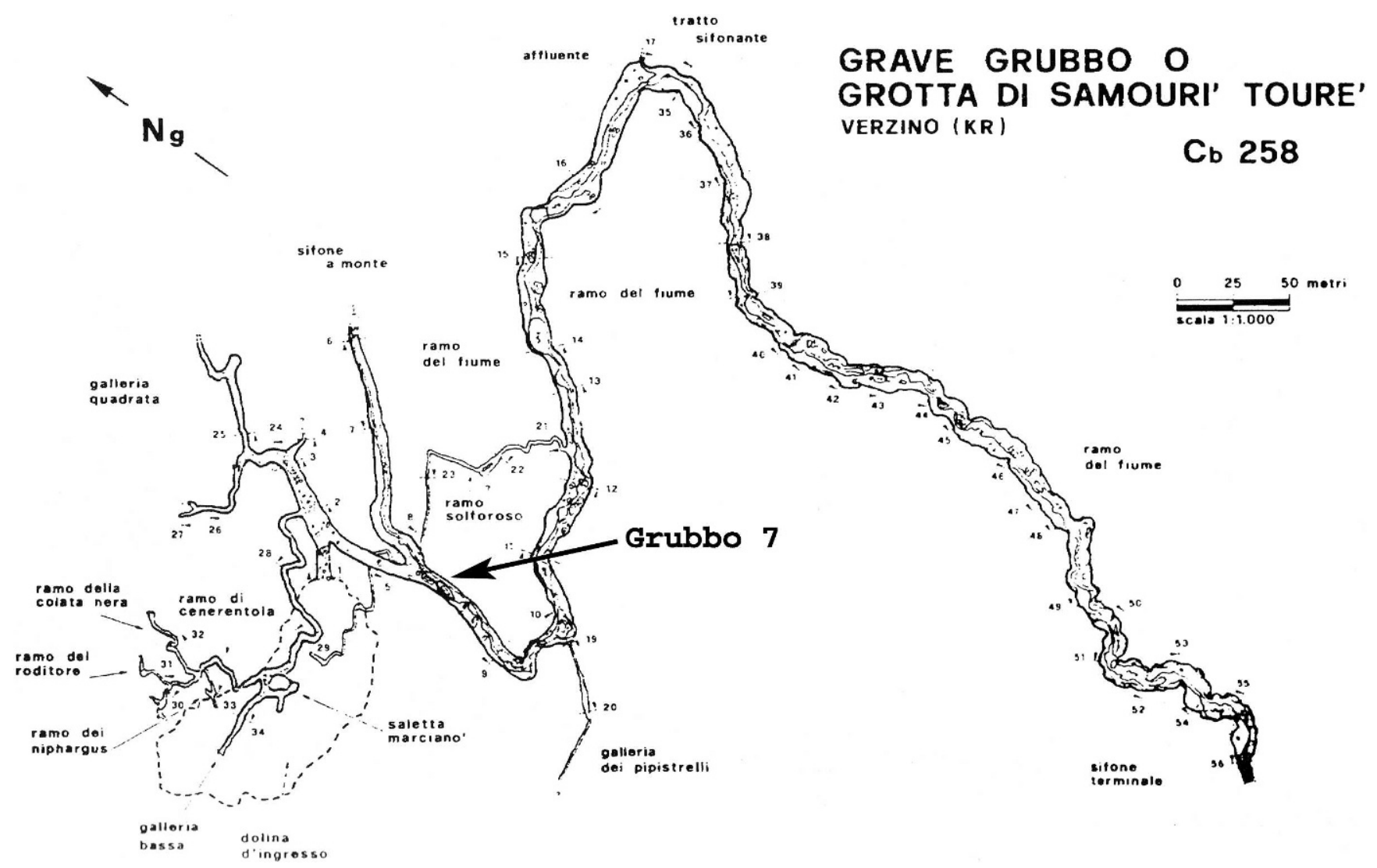

Figure 2. Map of Grave Grubbo Cave (Forti and Lombardo, 1998). Sampling site is at Grubbo 7, shown by the arrow; the entrance is labeled dolina d'ingresso.

the surface of agar plates, which were then incubated in the presence of air at $4,15,22$, and $32{ }^{\circ} \mathrm{C}$. We examined plates periodically under a light microscope to monitor crystal production for up to 40 days after inoculation. For negative controls, we checked for the presence of crystals in

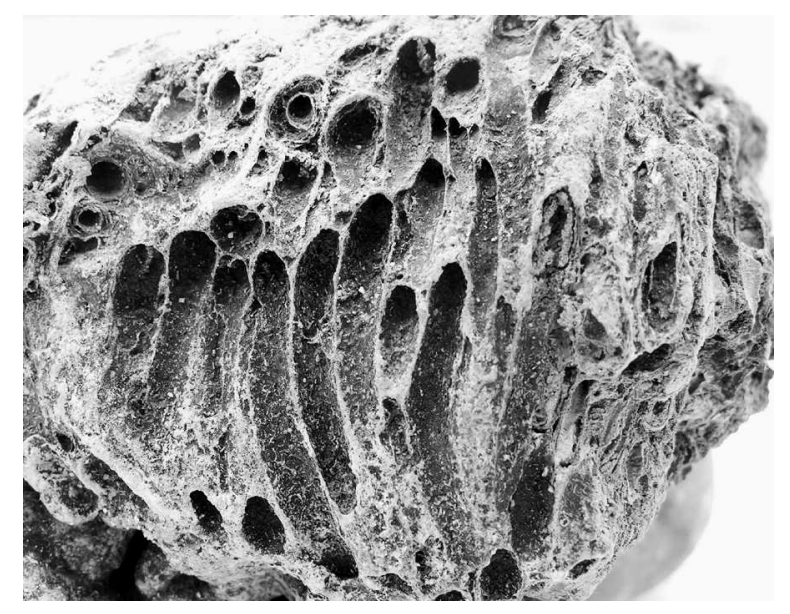

Figure 3. Macroscopic morphology of the newly described speleothem from Grave Grubbo Cave showing the tubes with mean of inner diameter $4.24 \mathrm{~mm}$ (Poluzzi and Minguzzi, 1998). sterile medium and medium inoculated with autoclaved bacteria.

Crystals produced by cultured bacteria were removed from the medium by cutting out agar blocks and placing them in boiling water until the agar dissolved. The supernatants were decanted, and the sediment was resuspended and washed in distilled water until the crystals were free of impurities (Rivadeneyra et al., 1998). The washed crystals were air-dried at $37{ }^{\circ} \mathrm{C}$ and then used to determine $\mathrm{CaCO}_{3}$ yield, crystal-phase, stable carbon and oxygen isotope compositions, and morphology.

The carbonate yield of the crystals obtained after three months of incubation was expressed as a percentage of the theoretical dry weight of calcium carbonate by dividing the experimental dry weight of the crystals by the theoretical dry weight. The theoretical dry weight of calcium carbonate was the stoichiometric quantity obtained from the $18 \mathrm{mg} \mathrm{Ca}^{2+}$ contained in each plate. The experimental dry weight of $\mathrm{CaCO}_{3}$ was the mean of the values obtained from four independent experiments. Data were analyzed using the Student's $t$-test.

$\mathrm{X}$-ray diffraction (XRD) measurements were done by a two-circle $\mathrm{t} / 2 \mathrm{t}$ diffractometer with a $\mathrm{Cu}$ radiation source, secondary graphite monochromator, and scintillation detector (Seifert MZ IV). The supply voltage of the X-ray 
P. Cacchio, C. Ercole, R. Contento, G. Cappuccio, M.P. Martinez, M. Del. Gallo and A. Lepidi

Table 1. Identification and culture traits of the calcifying isolates from Grave Grubbo Cave (Calabria, Southern Italy).

\begin{tabular}{llcccccc}
\hline Strains & Microorganism & Gram & Catalase & Oxidase & Urease & $\mathrm{NO}_{3}^{-} \rightarrow \mathrm{NO}_{2}^{-}$ & Anaerobiosis \\
\hline $\mathrm{G} 1$ & Bacillus magaterium & + & + & - & + & + & $+/-$ \\
$\mathrm{G} 2$ & Burkholderia sp. & - & + & - & + & + & $+/-$ \\
$\mathrm{G} 3$ & Pasteurella sp. & - & + & - & + & + & - \\
G6 & Staphylococcus sp. & + & + & - & + & + & - \\
G5 & Burkholderia sp. & - & + & - & + & + & - \\
G6 & Brevibacillus brevis & + & + & - & + & + & $+/-$ \\
G7 & Not identified & - & + & - & + & + & - \\
G8 & Actinomyces sp. & + & + & - & + & nd & + \\
\hline
\end{tabular}

Note: $+/-=$ minimal growth and $\mathrm{nd}=$ not determined.

tube was set at $50 \mathrm{kV}$ and $30 \mathrm{~mA}$. The $2 \mathrm{t}$ scan range was between $22^{\circ}$ and $50^{\circ}$; and each scan was done in steps of $0.05^{\circ}$. A counting time between one and ten seconds per step was selected, depending on the sample density. The crystalline phases were identified using the ICDD (International Center for Diffraction Data) database cards (JCPDS $=$ Joint Commitee on Powder Diffraction Standards).

We used a simple procedure for recognizing the crystalline phases present in each specimen. Cultured solid media samples were dried at $22^{\circ} \mathrm{C}$ or $32^{\circ} \mathrm{C}$. Agar medium was cut into $10 \times 30 \mathrm{~mm}$ flat blocks, $0.5 \mathrm{~mm}$ high, and those richest in crystallites were fixed on adhesive tape. This self-supporting film was put into the center of the diffractometer using a U-shaped sample holder to minimize background signals. For crystallite-poor samples, the agar was dissolved and crystals were collected according to the Rivadeneyra et al. method (1998). The washed crystals were air-dried at $37{ }^{\circ} \mathrm{C}$ and then supported on a glass slide for X-ray measurements.

Morphology characteristics were studied by scanning electron microscopy (SEM). Cultured solid-media samples were dried at $37^{\circ} \mathrm{C}$; agar medium was cut into flat blocks. For crystallite- poor samples, the agar was dissolved and crystals were collected and purified according to the Rivadeneyra et al. method (1998). To observe the inner portion of the bioliths, crystals were first powdered using a mortar and pestle. All samples were gold-shadowed and observed with a Philips SEM XL30CP.

For $\delta^{13} \mathrm{C}$ and $\delta^{18} \mathrm{O}$ analyses, carbonates $(1 \mathrm{mg})$ obtained in vitro or from Grave Grubbo Cave were dissolved at 70 ${ }^{\circ} \mathrm{C}$ in a KIEL II carbonate device (modified by McCrea, 1950). The $\mathrm{CO}_{2}$ produced was analyzed using a FinniganMat 252 mass spectrometer. Data relative to the V-PDB standard are reported using the conventional notation as previously specified (Cacchio et al., 2004).

Bacterial isolates displaying calcification were also tested for calcium carbonate dissolution by growing colonies on Deveze-Bruni medium (pH 6.8) containing 0.14\% or $2.5 \% \mathrm{CaCO}_{3}$ at $32{ }^{\circ} \mathrm{C}$ (NORMAL Commision, 1990). We quantified carbonate solubilization after 7, 15, and 30 days by measuring the diameter of the clear halo that surrounded each colony in response to decreased $\mathrm{pH}$ (Martino et al., 1992).

\section{Results AND Discussion}

Microbiological analysis of the sample from the upper layer of the calcareous speleothem from Grubbo Cave led to the isolation of sixteen bacterial isolates. Eight of these were obtained from the outer sub-sample and eight were from the inner sub-sample. Based on the colony morphologies of the isolates, we concluded that each subsample contained the same eight isolates and numbered them from G1 to G8. These results demonstrate the existence of a microflora of culturable heterotrophic bacteria that was autochthonous to this substrate. The two subsamples contained similar densities of heterotrophic bacteria culturable in the B-4 medium, $3.4 \times 10^{4} \mathrm{cfu} \mathrm{g}^{-1}$ (dry weigh) for the outer sample and $2.0 \times 10^{4} \mathrm{cfu} \mathrm{g}^{-1}$ (dry weight) for the inner sample, which indicated that the isolates were homogeneously distributed throughout the calcareous body. A similar microbial density has been reported for the calcareous speleothems of the Stiffe and Cervo Caves (Cacchio et al., 2003b and 2004, respective1y). The abundance of culturable bacterial cells isolated from the Grave Grubbo speleothem suggests that their presence was not accidental.

The isolates were present in similar proportions in the inner and outer sub-samples. The G4 isolate was the most abundant, representing $81 \%$ of the population, whereas G5 represented $11 \%$. The contributions of the G1, G2, G3, G6, $\mathrm{G} 7$ and G8 isolates to the overall population ranged from 0.3 to $5.4 \%$. These results are interesting, but may not reflect the actual microbial activity taking place in the speleothem, as cultivation techniques are thought to greatly underestimate microbial diversity due to the non-culturability of the large majority of microorganisms (Dojka et al., 2000).

The results of the characterization tests and the species we identified are shown in Table 1. Most isolates were aerobic rod-shaped bacteria, of which $50 \%$ were Grampositive. The most abundant isolate, G4, was an aerobic, spherical-shaped Gram-positive bacterium. It has been reported in the literature that Gram-positive cocci and coccoid forms are extremely common in soil and in undisturbed environments such as the Grave Grubbo and Cervo caves (Cacchio et al., 2004). All the calcifying bacteria reduced nitrate and hydrolyzed urea. Both of these 


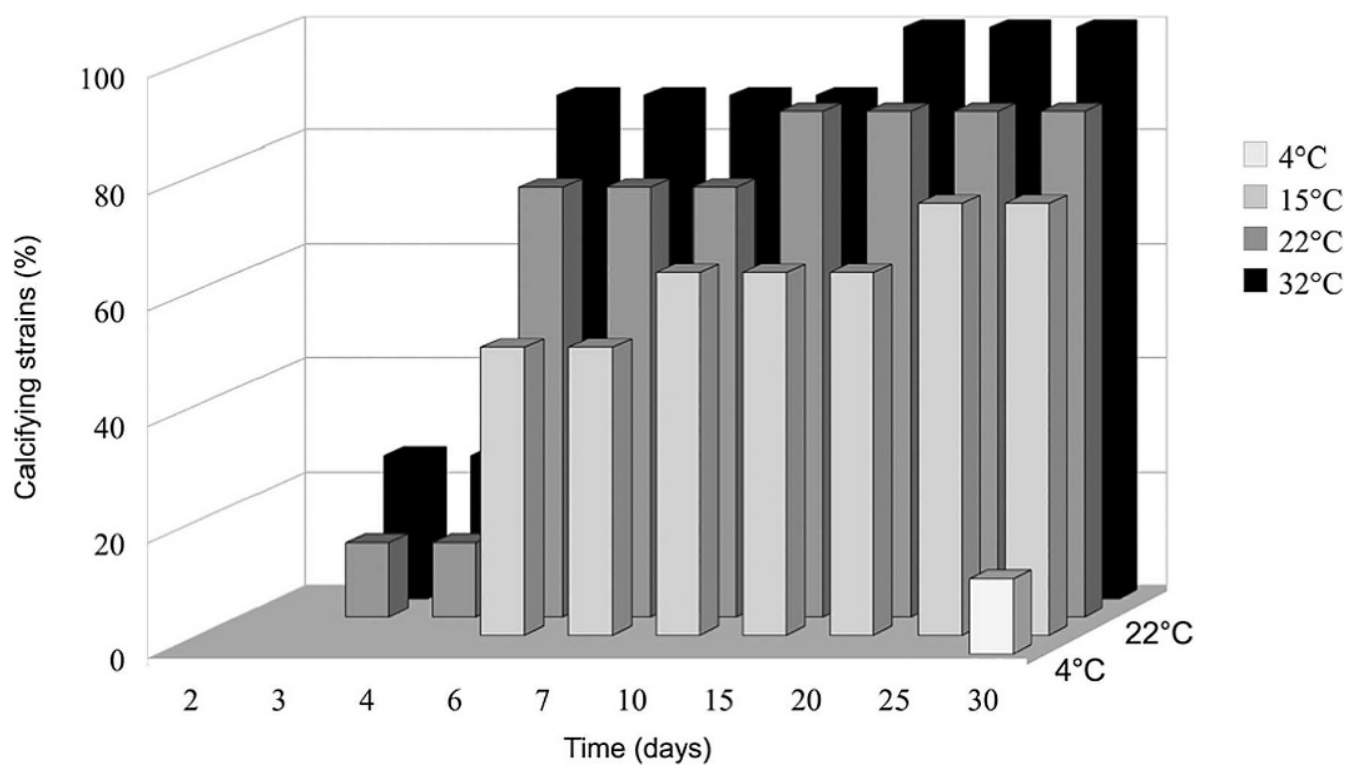

Figure 4. Relationship between the percentage of strains that were calcifying on $\mathrm{B}-4$ solid medium at 4 , 15,22 , and $32{ }^{\circ} \mathrm{C}$ and the number of days in culture. G7 and G8 did not survive and are not included in the percentages.

metabolic activities might be involved in the precipitation of calcium carbonate in caves (Castanier et al., 1999). Possible sources of nitrates in caves include bat guano, organic-rich ammonia or ammonium ions carried in from surface soils, ammonium-urea from amberat (cave rat urine), bacterial nitrogen fixation, fertilizers, volcanic rocks, and forest litter (Barton and Northup, 2007).

The API System identified seven of the eight calcifying bacterial isolates obtained from the Grave Grubbo speleothem to the genus level (Table 1). The species of 50\% of the isolates were scored with low discrimination because the API test bank, which is designed to identify pathogenic species, occasionally misidentifies subsurface isolates (Amy et al., 1992). Isolates G1 and G6 were related to Bacillus genus (Bacillus megaterium and Brevibacillus brevis, respectively). Bacillus strains were the most common calcifying bacteria found in the Stiffe Cave (Cacchio et al., 2003b). Isolates G2 and G5 were identified as Burkholderia sp. The most abundant isolate, G4, was related to Staphylococcus sp. Isolate G7 was not identified. Isolate G8, which was the only one displaying pseudomyceliar growth, was related to Actinomyces sp.

Amati and Gualandi (1934) isolated Bacillus violaceus and Micrococcus flavus liquiefaciens from samples taken from the Gortani Cave, which is in a gypsum outcrop near Bologna. A study of the microbial populations in the Novella Cave (Farneto, Gessi Bolognesi Regional Park) identified many bacterial (Bacillus sp., Serratia sp., and Acinetobacter sp.) and mold (Cryptococcus sp., Penicillium sp., Mucor sp., and Candida sp.) species and their connections to the cave.

Under laboratory conditions, 100 percent of the isolates formed crystalline $\mathrm{CaCO}_{3}$ in B-4 medium. This percentage is higher than what we found in samples from the Stiffe and Cervo Caves (96\% and 75\%, respectively) (Cacchio et al., 2003a,b, 2004). This result is consistent with those of several other studies and confirms that in appropriate conditions many bacteria are capable of forming $\mathrm{CaCO}_{3}$ crystals (Boquet et al., 1973).

$\mathrm{CaCO}_{3}$ precipitation occurred at all temperatures tested, $4,15,22$, and $32{ }^{\circ} \mathrm{C}$. The initiation of precipitation by all the calcifying isolates took longer at 4, 15, and 22, than at $32{ }^{\circ} \mathrm{C}$. All of the calcifying isolates began to precipitate $\mathrm{CaCO}_{3}$ after three weeks at $32{ }^{\circ} \mathrm{C}$ (Fig. 4) and after six weeks at 4,15 , and $22{ }^{\circ} \mathrm{C}$ (data not shown). No crystals were detected in the uninoculated controls or in the controls inoculated with autoclaved bacterial cells.

The relationships between $\mathrm{CaCO}_{3}$ yield and temperature under laboratory conditions depended on the isolate

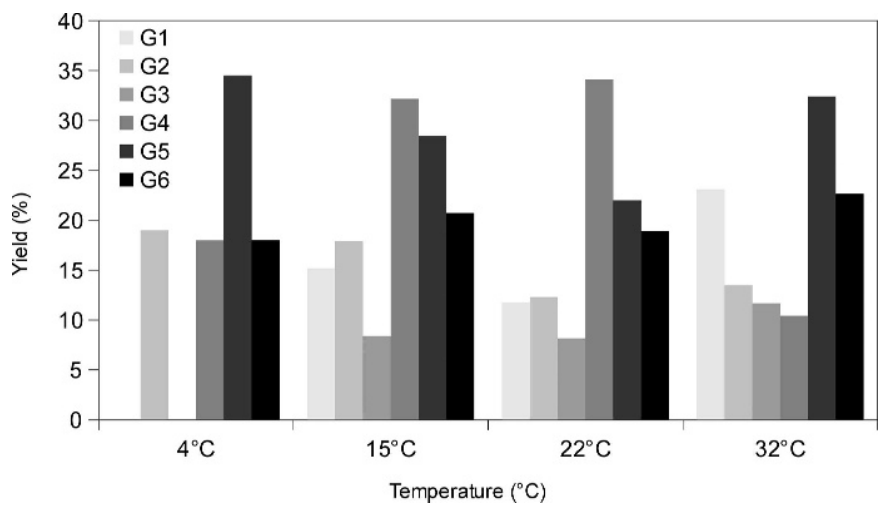

Figure 5. In vitro $\mathrm{CaCO}_{3}$ yield at $4,15,22$, and $32{ }^{\circ} \mathrm{C}$. The experimental dry weights are the means of four values obtained from independent experiments. 


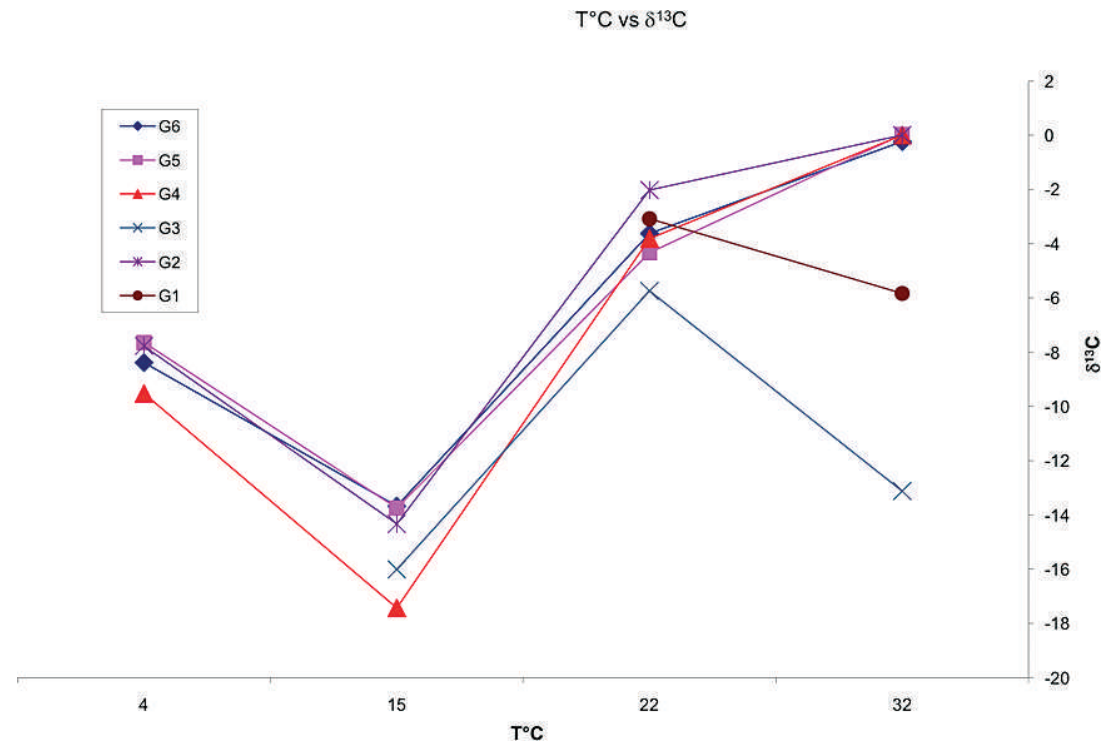

Figure 6. Carbon isotope composition $(\%)$ versus temperature $\left({ }^{\circ} \mathrm{C}\right)$ of calcium carbonates produced in vitro by the calcifying bacterial isolates.

(Fig. 5). The most abundant isolates, G4 and G5, which belonged to the Staphylococcus and Burkholderia genera, respectively, produced the largest amount of crystals at 15 ${ }^{\circ} \mathrm{C}$ (Fig. 5). In a previous report, we suggested that the ability to precipitate $\mathrm{CaCO}_{3}$ may be advantageous and subject to evolutionary selection in a cave environment (Cacchio et al., 2003b). Calcium carbonate deposition is useful to bacteria cells that remain in situ taking advantage of nutritive molecules present in the water, like corals do. In the case of the speleothem of the Grave Grubbo Cave, carbonatogenesis might keep the calcifying bacteria in place, and calcifying cells may avoid being washed out by the flow of the underground river.
The calcium carbonate yields of the strains G7 and G8 are not available. These isolates suffered during the transition from the starved, oligotrophic conditions of cave environments to the eutrophic conditions of nutrient agar and died before crystals could be recovered. It may be difficult for microorganisms from nutrient-poor cave environments to adapt to the sudden presence of nutrients in a laboratory environment, and they may simply die from osmotic stress (Koch, 1997). In adapting to cave environments, microorganisms employ elaborate mechanisms to pull scarce nutrients into the cell. When these highlyadapted organisms are then exposed to the rich nutrients of laboratory media, these extreme scavenging mechanisms

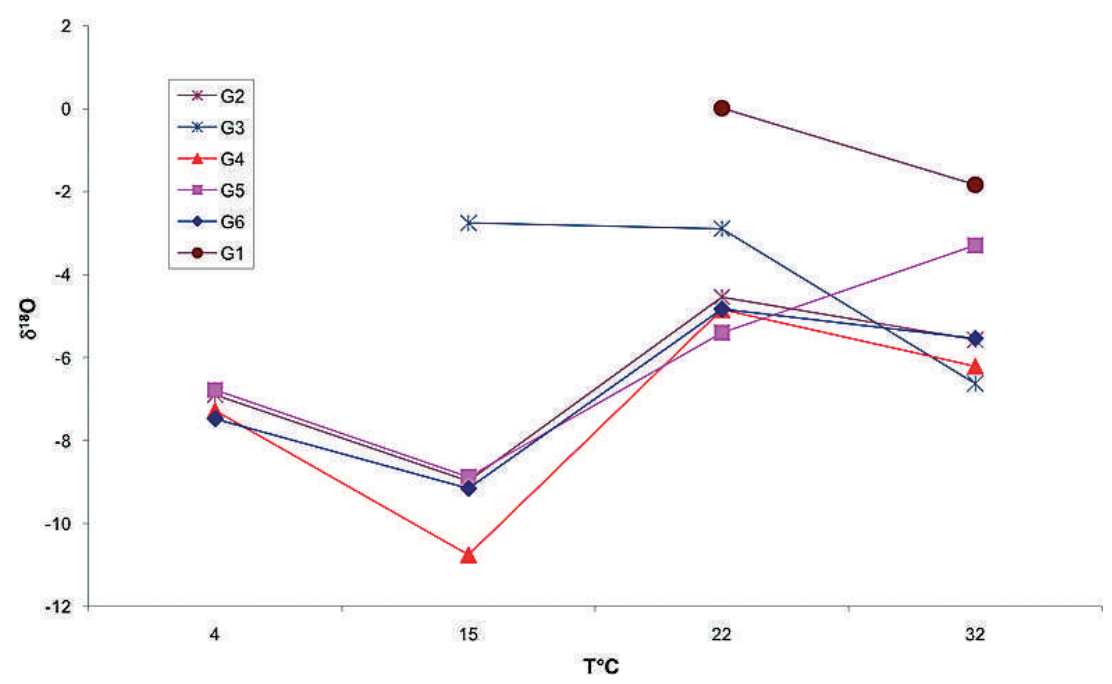

Figure 7. Oxygen isotopic composition $(\%)$ versus temperature $\left({ }^{\circ} \mathrm{C}\right)$ of calcium carbonates produced in vitro by the calcifying bacterial isolates. 


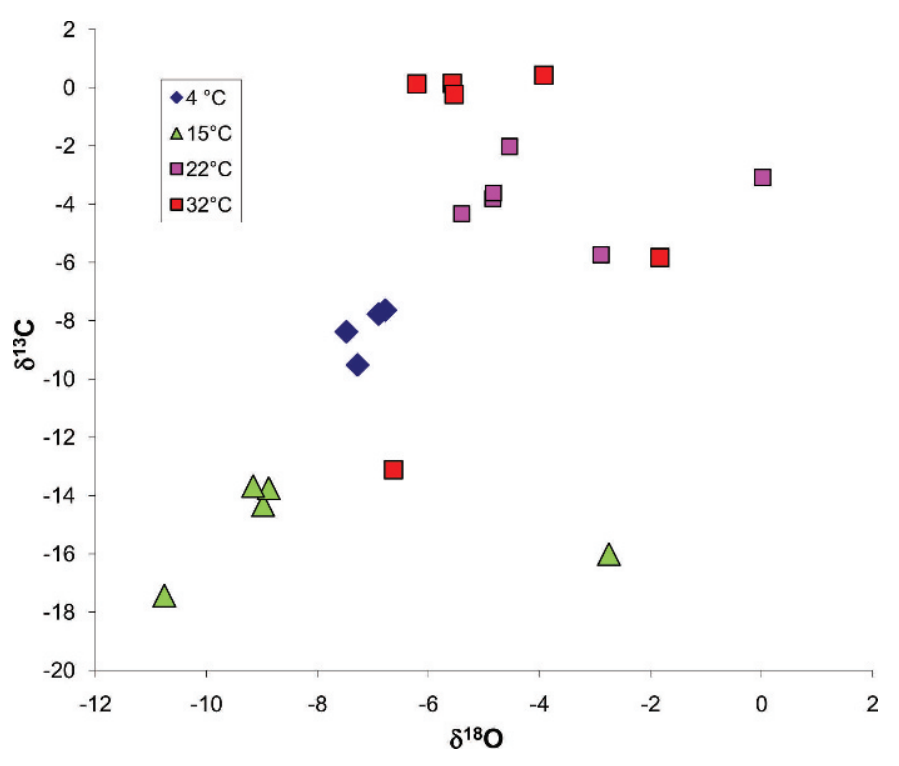

Figure 8. Correlation between $\delta^{13} \mathrm{C}$ and $\delta^{18} \mathrm{O}$ values (\%) of the calcium carbonates precipitated in vitro by the calcifying isolates.

continue unabated and the bacteria quickly gorge themselves to death (Koch, 1997, 2001).

Xray-diffraction analysis showed that all the calcifying bacteria produced calcite and that Burkholderia sp. also deposited vaterite in trace amounts $(<1 \%)$ at $15^{\circ} \mathrm{C}$ (data not shown). Vaterite precipitation was both species-specific and temperature-dependent. XRD analysis of the speleothem revealed the presence of calcite in large amounts, quartz in small amounts, and aragonite and gibbsite in traces. None of the isolates precipitated calcium carbonate in the form of aragonite.

The isotopic analysis performed on the carbonate concretion of the speleothem has shown medium values for $\delta^{13} \mathrm{C}$ and $\delta^{18} \mathrm{O}$ of $-6.4 \%$ and $-5.7 \%$, respectively. Previous studies (Turi, 1986) have shown that values for $\delta^{13} \mathrm{C}$ lower than $-4 \%$ indicate that in addition to "heavy" carbon from the dissolution of carbonatic rocks, "light" biogenic carbon, which is plant-derived $\mathrm{CO}_{2}$ dissolved in the soil, must also contribute to calcite precipitation. On the other hand, many of the carbonatic concretions of microbial origin show $\delta^{13} \mathrm{C}$ values similar to the values found in the Grave Grubbo speleothem (Andrews et al., 1997). The $\delta^{18} \mathrm{O}$ values are compatible with precipitation at equilibrium from meteoric water at cave temperature (O'Neil et al., 1969). From these observations, oxygen and carbon fractionation due to the presence of calcifying bacteria cannot be ruled out, although the environmental conditions (temperature, $\delta^{18} \mathrm{O}$ in the water, carbon derived from inorganic and organic sources, etc.) are essential in defining the isotopic composition of the calcite concretions of caves. In addition, analysis of the carbon and oxygen isotopes of carbonates produced in vitro showed that, first, the isotopic composition of the calcium carbonates produced by the different bacterial isolates depended more on temperature than on the type of bacterial isolate (except for G3) and, second, at cave temperature $\left(15^{\circ} \mathrm{C}\right)$, the most abundant isolate, Staphylococcus sp., produced the largest amount of crystals and precipitated the carbonates most depleted in ${ }^{13} \mathrm{C}$ and ${ }^{18} \mathrm{O}$ (Figs. 6 and 7). A positive correlation existed between the $\delta^{13} \mathrm{C}$ and $\delta^{18} \mathrm{O}$ values of the crystals (Fig. 8).

It was not possible to compare the $\delta^{13} \mathrm{C}$ and $\delta^{18} \mathrm{O}$ values obtained of the carbonates produced in vitro with the values of the concretions of the cave because the composition of the cave's sources of carbon and oxygen are unknown.

Bacillus megaterium isolates precipitated various biominerals in vitro, predominantly spherulites consisting of isolated spheres or forming groups of spheres (Fig. 9a,b,c). Biofilms were observed as non-calcareous bridges among the crystals (Fig. 9b,c). Hemispherical forms were also present with radial inner surfaces (Fig. 9d,e,f). The outer surfaces of these structures were frequently rough due to the de novo deposition of calcium carbonate (Fig. 9a,d,e). In a previous study, we obtained nine isolates of Bacillus megaterium (Cacchio et al., 2003b). SEM analysis revealed that some of those isolates produced spherical or hemispherical crystals similar to those produced by the G1 isolated here. Isolate G6, Brevibacillus sp., also produced spherical crystals. Pasteurella sp. precipitated irregularly shaped bioliths that tended to aggregate. Staphylococcus sp. deposited globular crystals with a rough outer surface. Burkholderia isolates produced elliptical crystals with a scaly surface. The inner portions of these bioliths contained imprints that were similar in size and shape to the bacterial cells (Fig. 9g,h,i,1). We did not analyze the carbonates produced by the G7 isolate and Actinomyces sp. by SEM. The different morphologies of the precipitates formed by the different calcifying isolates confirmed that crystal mor-

Figure 9. Scanning electron micrographs of the bioliths precipitated on B-4 agar by Bacillus megaterium (a,b,c,d,e,f) and Burkholderia sp. (g,h,i,l) isolated from the novel calcite structure in Grave Grubbo Cave, Southern Italy. a) Two individual intergrowing bioliths; scale bar $20 \mu \mathrm{m}$. b) A large aggregate of individual crystals bound by means of non-globular carbonate bridges; scale bar $20 \mu \mathrm{m} . c$ ) A higher magnification of the biofilm; scale bar $10 \mu \mathrm{m}$. d) Radially arranged hemispherical calcium carbonate crystal; scale bar $20 \mu \mathrm{m}$. $e$ ) The outer surface of the biolith characterized by de novo deposition of calcium carbonate; scale bar $20 \mu \mathrm{m} . f$ ) Fragment of a crystal showing a three-layered structure; scale bar $20 \mu \mathrm{m} . g$ ) The inner surface 


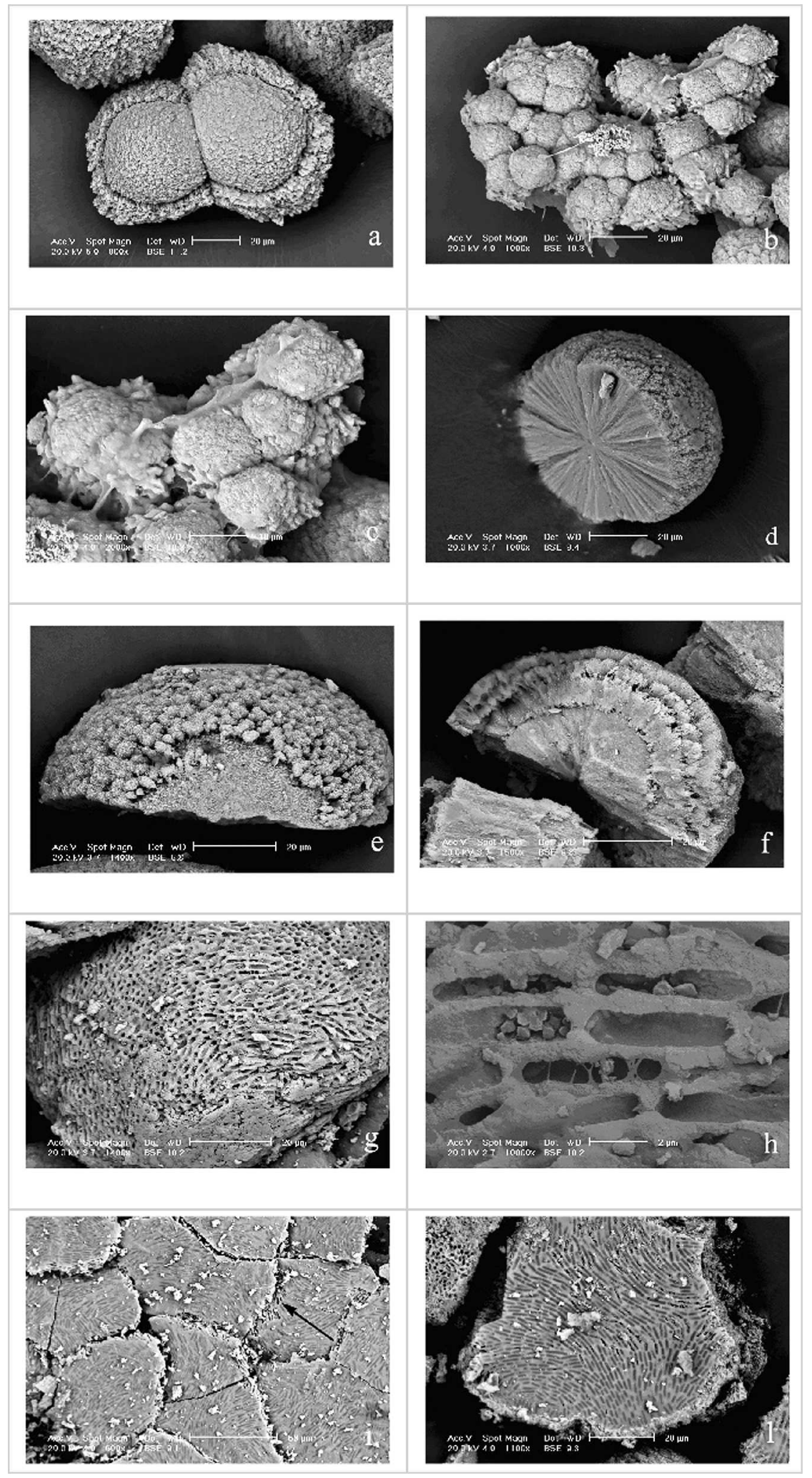

shows microbial imprints similar in size and shape to the microbial rods; scale bar $20 \mu \mathrm{m} . h$ ) A higher magnification of the internal porous structure of the biolith; scale bar $20 \mu \mathrm{m} . i$ ) Calcium carbonate layer with bacterial imprints arranged in a geometric stream disposition; scale bar $50 \mu \mathrm{m}$. l) Detail of $i$; scale bar $20 \mu \mathrm{m}$. 


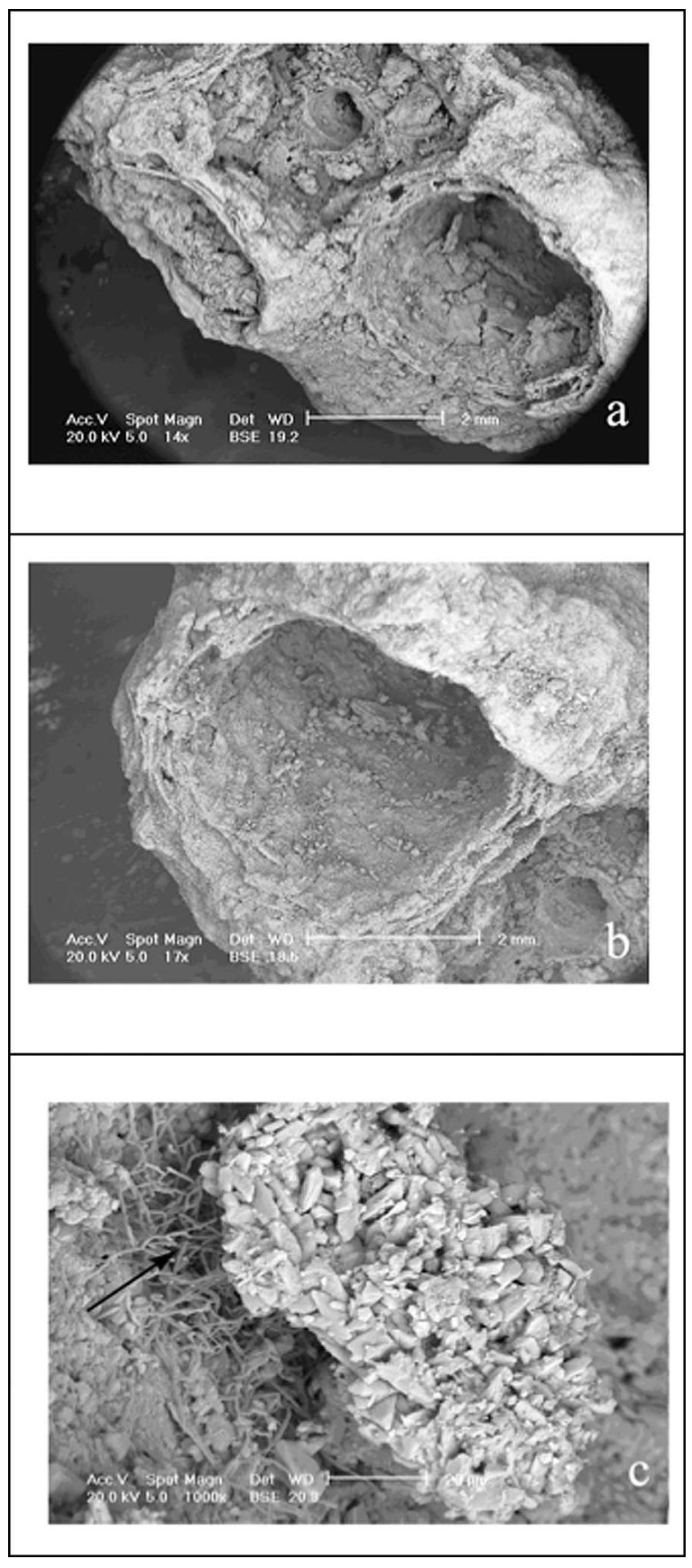

Figure 10. SEM images of cave crystals collected from the speleothem in Grave Grubbo Cave. a) Cross-section of the aggregate showing the outer-inner laminae and the middle, sponge-like septa. $b$ ) Detail of $a$. $c$, Spike crystals deposited after tube formation are likely to occlude the lumen of the tube. Filamentous calcified bacteria interacting with the calcite layer (arrow).

phology was species-specific, suggesting that the bacteria play a major role in the precipitation process.

Some crystals exhibited bacterial imprints arranged in a geometric stream disposition (Fig. 9g,i,1). This particular imprint pattern may be due to the involvement of quorum sensing in colony growth (Branda et al., 2004). Quorum sensing is a process of cell-to-cell communication that bacteria use to assess their population density to coordinate gene expression of the community (Miller and Bassler, 2001). Quorum sensing requires production, secretion, and detection of extracellular signal molecules called autoinducers, some of which are used for intraspecies communication, while others promote interspecies communication (Federle and Bassler, 2003). Many gram-negative bacterial species use acyl homoserine lactones (AHLs) as autoinducers. Quorum sensing controls several important functions in bacteria, including the production of virulence factors and biofilm formation. We hypothesize that this cell-to-cell communication may be also involved in the calcification process. To this aim, we produced an $\mathrm{AHL}^{-}$mutant of the strain PHP7 of Burkholderia cepacia. The $\mathrm{AHL}^{-}$mutant grown on B-4 agar plates lost the calcifying capability of the wild type strain (preliminary data not published).

The SEM analysis of the speleothem material confirm the layered organization of the tube body that was apparent upon observation (Fig. 3), supporting the tubular structure of the calcareous body and the spongy structure of the three-layered wall (Fig. 10a,b). Calcified filamentous bacterial cells were detected between the outer wall of the tubes and the deposited calcite (Fig. 10c), which partially occluded the lumen of the tubes (Fig. 10a). Finally, only the $\mathrm{G} 7$ isolate was able to solubilize $\mathrm{CaCO}_{3}(0.14 \%)$, after one week at $32{ }^{\circ} \mathrm{C}$.

\section{Conclusions}

Within the past two decades, growing interest in cave microbiota has helped to recognize and understand the importance of microbial species in caves. Studies of cave microbiology have identified a wide variety of different cave-dwelling microorganisms, revealed how these organisms interact with and adapt to the cave environment, and disclosed their roles in creating and destroying secondary mineral deposits. Most of the research involving the gypsum areas in Italy has been carried out since 2000 on samples from caves located in the large gypsum areas of Sicily, Calabria, and Emilia.

Microbes cycle nutrients within cave environments. The processes of ammonification, nitrification, denitrification, and nitrogen fixation have all been documented to occur in caves. Sulfide and sulfur oxidizers and sulfate reducers are also found in caves. Nitrogen and the sulfur cycles may both occur, separately or concurrently, during heterotrophic bacterial carbonatogenesis in caves.

Microbes are critical to food-limited cave environments because they may act as primary producers in an environment lacking photosynthetic organisms.

Studies of sulfur bacteria have rapidly expanded in the last decade, reflecting the recent discoveries of sulfurcontaining caves, including Movile Cave in Romania. The 
food web of this cave is based on chemolithotrophic processes involving sulfur and other compounds. Among the Italian caves in the gypsum area, a remarkable number of sulfur bacteria have been isolated in the caves of Santa Ninfa, Sicily. Sulfur bacteria have also been detected in Grave Grubbo Cave, where a subterranean ecosystem driven by these chemoautotrophic microorganisms, as trophic symbionts of troglobitic insects able to agglutinate lithoid elements, has been hypothesized to be indirectly involved in the deposition of the unusual speleothem found in this cave.

We studied this peculiarly structured cave speleothem to determine whether heterotrophic bacterial carbonatogenesis was involved in its formation. The Grave Grubbo speleothem was found to contain a large number of culturable heterotrophic microorganisms, whose presence was likely not accidental. All the isolates obtained from the speleothem samples precipitated $\mathrm{CaCO}_{3}$ in vitro in agar containing calcium acetate. The relative abundance of each isolate was found to be related to carbonate yield at $15^{\circ} \mathrm{C}$, suggesting that calcification may be a selective advantage.

Isotopic analysis showed that, as previously suspected, the $\delta^{13} \mathrm{C}$ values of the Grave Grubbo speleothem were compatible with a biogenic origin and that the $\mathrm{CaCO}_{3}$ bioliths produced in vitro by the Staphylococcus sp., the most abundant isolate and the one that produce the largest amounts of carbonates in vitro at $15{ }^{\circ} \mathrm{C}$, had $\delta^{13} \mathrm{C}$ and $\delta^{18} \mathrm{O}$ values that were lighter than the carbonates produced in vitro by the other calcifying isolates. In conclusion, these isotopic data were consistent with calcifying bacteria making a significant contribution to the deposition of speleothem carbonates.

SEM images revealed the presence of calcified bacterial cells interacting with the calcite substrate of the speleothem, the presence of a biofilm among the bioliths obtained in vitro, the presence of bacterial imprints in the interior of the $\mathrm{CaCO}_{3}$ bioliths produced in vitro, and different species-specific morphologies among the bioliths obtained in vitro. A typical stream-like organization of the bacterial imprints, observed in some instances, suggests that a quorum-sensing system may be involved in the calcium carbonate precipitation process.

Our data clearly demonstrate that calcifying bacteria isolated from this unusual calcareous speleothem hosted in the Grave Grubbo Cave are able to precipitate $\mathrm{CaCO}_{3}$ in vitro and may play an important role in the deposition of these cave crystals.

\section{ACKNOWLEDGEMENTS}

We thank G. Ferrini and A. Moretti for providing samples from the Grave Grubbo Cave and for the assistant with the geological considerations, and C. Veroli and M. Mola for their collaboration in powder diffraction measurements and stable isotope analysis, respectively. We also thank $\mathrm{M}$. Giammatteo and L. Arrizza for assistance with SEM and R. Di Stefano for assistance with the Calabria map.

\section{REFERENCES}

Amati, A., and Gualandi, C., 1934, La microflora di alcune acque cavernicole del sottosuolo bolognese, Naples, Riv. di Fisica, Matematica e Scienze Naturali, ser. 3, 16 p.

Amy, P.S., Haldeman, D.L., Ringelberg, D., Hall, D.H., and Russel, C., 1992, Comparison of identification systems for classification of bacteria isolated from water and endolithic habitats within the deep subsurface: Applied and Environmental Microbiology, v. 58, no. 10, p. $3367-3373$.

Andrews, J.E., Riding, R., and Dennis, P.F., 1997, The stable isotope record of environmental and climatic signals in modern terrestrial microbial carbonates from Europe: Palaeogeography, Palaeoclimatology, Palaeoecology, v. 129 , p. 171-189, doi:10.1016/S0031-0182 (96)00120-4.

Barton, H.A., and Northup, D.E., 2007, Geomicrobiology in cave environments: past, current and future perspectives: Journal of Cave and Karst Studies, v. 69, no. 1, p. 163-178.

Baskar, S., Baskar, R., Lee, N., and Theophilus, P.K., 2009, Speleothems from Mawsmai and Krem Phyllut caves, Meghalaya, India: some evidences on biogenic activities: Environmental Geology, v. 57, no. 5, p. 1169-1186, doi:10.1007/s00254-008-1413-y.

Baskar, S., Baskar, R., Mauclaire, L., and McKenzie, J.A., 2006, Microbially induced calcite precipitation in culture experiments: Possible origin for stalactites in Sahastradhara caves, Dehradun, India: Current Science, v. 90, p. 58-64.

Boquet, E., Boronat, A., and Ramos-Cormenzana, A., 1973, Production of calcite (calcium carbonate) crystals by soil bacteria is a general phenomenon: Nature, v. 246, p. 527-529, doi:10.1038/246527a0.

Branda, S.S., Gonzáles-Pastor, J.E., Dervyn, E., Ehrlich, S.D., Losick, R., and Kolter, R., 2004, Genes involved in formation of structured multicellular communities by Bacillus subtilis: Journal of Bacteriology, v. 186, p. 3970-3979, doi:10.1128/JB.186.12.3970-3979.2004.

Cacchio, P., Contento, R., Ercole, C., Cappuccio, G., Preite Martinez, M., and Lepidi, A., 2004, Involvement of microorganisms in the formation of carbonate speleothems in the Cervo Cave (L'Aquila-Italy): Geomicrobiology Journal, v. 21, p. 497-509, doi:10.1080/01490450490888109.

Cacchio, P., Ercole, C., and Lepidi, A., 2003a, Calcium carbonate deposition in limestone caves: microbiological aspects: Subterranean Biology, v. 1, p. 57-63.

Cacchio, P., Ercole, C., Cappuccio, G., and Lepidi, A., 2003b, Calcium carbonate precipitation by bacterial strains isolated from a limestone cave and from a loamy soil: Geomicrobiology Journal, v. 20, p. 85-98, doi:10.1080/01490450303883.

Cañaveras, J.C., Hoyos, M., Sanchez-Moral, S., Sanz-Rubio, E., Bedoya, J., Soler, V., Groth, I., Schumann, P., Laiz, L., Gonzales, I., and SaizJimenez, C., 1999, Microbial communities associated with hydromagnesite and needle-fiber aragonite deposits in a karstic cave (Altamira, northern Spain): Geomicrobiology Journal, v. 16, p. 9-25, doi:10.1080/014904599270712.

Cañaveras, J.C., Sanchez-Moral, S., Soler, V., and Saiz-Jimenez, C., 2001, Microorganisms and microbially induced fabrics in cave walls: Geomicrobiology Journal, v. 18, p. 223-240, doi:10.1080/01490450 152467769 .

Castanier, S., Le Metayer-Levrel, G., and Perthuisot, J.-P., 1999, Cacarbonates precipitation and limestone genesis - the microbiogeologist point of view: Sedimentary Geology, v. 126, p. 9-23, doi:10.1016/ S0037-0738(99)00028-7.

Castanier, S., Le Métayer-Levrel, G., and Perthuisot, J.-P., 2000, Bacterial roles in the precipitation of carbonate minerals, in Riding, R.E., and Awramik, S.M., eds., Microbial Sediments, Berlin, Springer-Verlag, p. 32-39.

Dojka, M.A., Harris, J.K., and Pace, N.R., 2000, Expanding the known diversity and environmental distribution of an uncultured phylogenetic division of bacteria: Applied and Environmental Microbiology, v. 66 , no. 4 , p. $1617-1621$.

Ehrlich, H.L., 2002, Geomicrobiology, 4th edition, CRC Press, 768 p.

Ercole, C., Cacchio, P., Botta, A.L., Centi, V., and Lepidi, A., 2007, Bacterially induced mineralization of calcium carbonate: the role of exopolysaccharides and capsular polysaccharides: Microscopy and Microanalysis, v. 13, p. 42-50, doi:10.1017/S1431927607070122.

Federle, M.J., and Bassler, B.L., 2003, Interspecies communication in bacteria: The Journal of Clinical Investigation, v. 112, p. 1291-1299, doi:10.1172/JCI20195. 
Ferrini, G., ed., 1998, L'area carsica delle vigne (Verzino-Crotone) Studio multidisciplinare (The karst area of "Le Vigne" - Verzino Crotone multidisciplinary researches): Memorie Istituto Italiano di Speleologia.

Ferrini, G., 1998, Litostratigrafia del complesso carsico Grave Grubbo Risorgiva Vallone Cufalo (Gessoareniti Messiniane del Bacino Crotonese): Memorie dell'Istituto Italiano di Speleologia, ser. 2, v. 10, p. $47-52$.

Forti, P., and Lombardo, N., 1998, I depositi chimici del sistema carsico Grave Grubbo - Risorgente di Vallone Cufalo (Verzino, Calabria): Memorie dell'Istituto Italiano di Speleologia, v. 10, p. 83-92.

Forti, P., Galdenzi, S., and Sarbu, S.M., 2002, The hypogenic caves: a powerful tool for the study of seeps and their environmental effects: Continental Shelf Research, v. 22, no. 16, p. 2373-2386, doi:10.1016/ S0278-4343(02)00062-6.

Galdenzi, S., and Menichetti, M., 1998, Aspetti morfologici ed evolutivi di un sistema carsico ipogeo nei gessi di Verzino (Calabria): Memorie dell'Istituto Italiano di Speleologia, ser. 2, v. 10, p. 71-82.

Groth, I., Schumann, P., Laiz, L., Sanchez-Moral, S., Cañaveras, C.J., and Saiz-Jimenez, C., 2001, Geomicrobiological study of the Grotta dei Cervi, Porto Badisco, Italy: Geomicrobiological Journal, v. 18, p. 241-258, doi:10.1080/01490450152467778.

Groth, I., Vettermann, R., Schuetze, B., Schumann, P., and Saiz-Jimenez, C., 1999, Actinomycetes in karstic caves of northern Spain (Altamira and Tito Bustillo): Journal of Microbiological Methods, v. 36, p. 115-122, doi:10.1016/S0167-7012(99)00016-0.

Koch, A.L., 1997, Microbial physiology and ecology of slow growth: Microbiology and Molecular Biology Reviews, v. 61, p. 305-318.

Koch, A.L., 2001, Oligotrophs versus copiotrophs: BioEssays, v. 23, p. 657-661, doi:10.1002/bies.1091.

Laiz, L., Gonzalez-Delvalle, M., Hermosin, B., Ortiz-Martinez, A., and Saiz-Jimenez, C., 2003, Isolation of cave bacteria and substrate utilization at different temperatures: Geomicrobiology Journal, v. 20, p. 479-489, doi:10.1080/713851125.

Laiz, L., Groth, I., Gonzales, I., and Saiz-Jimenez, C., 1999, Microbiological study of the dripping waters in Altamira cave (Santillana del Mar, Spain): Journal of Microbiological Methods, v. 36, p. 129-139, doi:10.1016/S0167-7012(99)00018-4

Laiz, L., Groth, I., Schumann, P., Zezza, F., Felske, A., Hermosin, B., and Saiz-Jimenez, C., 2000, Microbiology of the stalactites from Grotta dei Cervi, Porto Badisco, Italy: International Microbiology, v. 3, p. 25-30.

Le Métayer-Levrel, G., Castanier, S., Loubière, J.F., and Perthuisot, J.P., 1997, La carbonatogenèse bactérienne dans les grottes. Étude au MEB d'une hélictite de Clamouse, Hérault, France: Comptes Rendus de
l'Académie des Sciences Serie IIa: Sciences de la Terre et des Planets, v. 325 , p. 179-184, doi:10.1016/S1251-8050(97)88286-9.

McCrea, J.M., 1950, On the isotopic chemistry of carbonates and a palaeotemperature scale: Journal of Chemical Phyics, v. 18, p. 849857, doi:10.1063/1.1747785.

Martino, T., Salamone, P., Zagari, M., and Urzì, C., 1992, Adesione a substrati solidi e solubilizzazione del $\mathrm{CaCO}_{3}$ quale misura della capacità deteriorante di batteri isolati dal marmo Pentelico, in Italian Society of General Microbiology and Microbial Biotechnology (SIMGBM) XI Meeting, Gubbio; p. 249-250.

Melim, L.A., Shinglman, K.M., Boston, P.J., Northup, D.E., Spilde, M.N., and Queen, J.M., 2001, Evidence for microbial involvement in pool finger precipitation, Hidden Cave, New Mexico: Geomicrobiology Journal, v. 18, p. 311-329, doi:10.1080/01490450152467813.

Miller, M.B., and Bassler, B.L., 2001, Quorum sensing in bacteria: Annual Review of Microbiology, v. 55, p. 165-199, doi:10.1146/annurev.micro.55.1.165.

NORMAL Commission, 1990, NORMAL 9/88 recommendations. Microflora Autotrofa ed Eterotrofa: Tecniche di Isolamento in Coltura: Rome, Consiglio Nazionale Ricerche, Istituto Centrale Restauro, 26 p.

Northup, D.E., Dahm, C.N., Melim, L.A., Spilde, M.N., Crossey, L.J., Lavoie, K.H., Mallory, L.M., Boston, P.J., Cunningham, K.I., and Barns, S.M., 2000, Evidence for geomicrobiological interactions in Guadalupe caves: Journal of Cave and Karst Studies, v. 62, p. 80-90.

O’Neil, J.R., Clayton, R.N., and Mayeda, T.K., 1969, Oxygen isotope fractionation in divalent metal carbonates: Journal of Chemical Physics, v. 51, p. 5547-5558, doi:10.1063/1.1671982.

Poluzzi, A., and Minguzzi, V., 1998, Un caso di biocostruzione in un ambiente di grotta. L'area carsica delle Vigne di Verzino: Memorie dell'Istituto Italiano di Speleologia, ser. 2, v. 10, p. 93-100.

Riding, R., 2000, Microbial carbonates: the geological record of calcified bacterial-algal mats and biofilms: Sedimentology, v. 47, no. suppl. S1, p. 179-214, doi:10.1046/j.1365-3091.2000.00003.x.

Rivadeneyra, M.A., Delgado, G., Ramos-Cormenzana, A., and Delgado, R., 1998, Biomineralisation of carbonates by Halomonas eurihalina in solid and liquid media with different salinities: crystal formation sequence: Research in Microbiology, v. 149, p. 277-287.

Simkiss, K., and Wilbur, K.M., 1989, Biomineralization: Cell Biology and Mineral Deposition, San Diego, Academic Press, 337 p.

Turi, B., 1986, Stable isotope geochemistry in travertines, in Fritz, P., and Frontes, J.C., eds., Handbook of Environmental Isotope Geochemistry 2: The Terrestrial Environment: Elsevier, Amsterdam, p. 207-235. 